\title{
Tahap Kefahaman Pelajar Terhadap Penggunaan Modul PBL dalam Pendidikan Islam di Politeknik Brunei Darussalam
}

\author{
Aliff Nawia, Gamal Abdul Nasir Zakariaa*, Norkhairiah Hashim ${ }^{b}$ \\ ${ }^{a}$ Sultan Hassanal Bolkiah Institute of Education, Universiti Brunei Darussalam, Tunku Link Road, BE1410, Brunei \\ 'Politeknik Brunei Darussalam, Bandar Seri Begawan, BA1311, Brunei \\ *Corresponding author: gamal.zakaria@ubd.edu.bn
}

\begin{abstract}
This study was conducted to identify students' level of understanding and feedback on the use of PBL Module at Polytechnic Brunei Darussalam. PBL Modules are designed specifically for Islamic Education course and used by a total of 41 students throughout the semester. This study used a descriptive analysis (frequency, percentage and min) to see the level of students' understanding of the modules used. In addition, interviews with mini-focus groups were also conducted to obtain feedback on the module. The results showed that the students able to understand the module effectively and enhance students' understanding. Students also demonstrated increased awareness of critical thinking, concentration performance, advocate sharing information and team work engagement. The response also indicates that students prefer to use this module as well as to improve the quality of teaching and learning. PBL is expected module can be used as an alternative material that can be highlighted in the field of Islamic education in line with the demands of learning in the 21 st century.
\end{abstract}

Keywords: Understanding; modules; PBL; islamic education; polytechnics; Brunei

\begin{abstract}
Abstrak
Kajian ini bertujuan untuk mengenalpasti tahap kefahaman pelajar dan maklum balas terhadap penggunaan Modul iPBL di Politeknik Brunei Darussalam. Modul ini merupakan sebuah modul yang dibina khas bagi kursus Pendidikan Islam yang digunakan oleh seramai 41 orang pelajar selama satu semester. Kajian ini menggunakan analisis deskriptif (frekuensi, peratus dan min) untuk melihat tahap kefahaman pelajar terhadap modul yang digunakan. Selain itu, temubual bersama kumpulan mini-fokus juga dijalankan untuk mendapatkan maklum balas terhadap modul berkenaan. Dapatan menunjukkan bahawa tahap kefahaman pelajar adalah berada pada tahap yang tinggi dan baik. Maklum balas yang diterima juga menunjukkan bahawa modul yang digunakan dapat meningkatkan lagi kualiti pengajaran dan pembelajaran dalam kursus ini. Diharapkan Modul iPBL dapat dijadikan dijadikan bahan alternatif yang dapat diketengahkan dalam bidang Pendidikan Islam seiring dengan tuntutan pembelajaran pada abad ke-21.
\end{abstract}

Kata kunci: Kefahaman, modul, PBL, Pendidikan Islam, Politeknik, Brunei

(C) 2017 Penerbit UTM Press. All rights reserved

\subsection{PENDAHULUAN}

Modul merupakan satu unit pengajaran dan pembelajaran yang membincangkan sesuatu tajuk tertentu secara sistematik dan berturutan bagi memudahkan pelajar belajar secara bersendirian supaya dapat menguasai sesuatu unit pembelajaran dengan mudah dan tepat (Sidek \& Jamaludin, 2005). Modul juga dikenali sebagai pakej pembelajaran yang dilengkapi oleh pelbagai maklumat di mana pengguna boleh belajar secara bersendirian untuk mendapatkan pengetahuan atau kemahiran yang baru (Winkel, 2004). Robinson (1972) pula menyatakan bahawa pembelajaran menerusi modul bukan sahaja dapat memberi manfaat terhadap individu namun melibatkan pembelajaran secara berkumpulan. Menurut beliau, antara manfaat yang diperoleh termasuklah dapat meminimakan keperluan untuk teknik pembelajaran konvensional bersifat verbal, membolehkan guru menganalisis proses pembelajaran, menambah baik pembelajaran melalui penambahbaikan dalam penilaian, memaksimakan keberkesanan penggunaan media pengajaran dan pembelajaran dapat berlangsung walaupun tanpa kehadiran guru.

Modul juga boleh berfungsi untuk kegunaan sesuatu proses pengajaran seperti sistem pengajaran peribadi. Penggunaan modul dalam pengajaran dan pembelajaran dapat menyampaikan isi kandungan dengan berturutan, iaitu sedikit demi sedikit atau dengan menggunakan langkah khusus bagi mencapai objektif pengajaran yang telah ditetapkan terlebih dahulu (Rosnah, 2002). Modul turut direka bentuk berasaskan kepada unit kecil pembelajaran yang terdapat dalam sukatan pelajaran (Yusuf, 1997). Hal ini demikian bermakna bahawa, tiaptiap unit pembelajaran ini dipilih, disusun dan dikumpul untuk dijadikan satu modul yang lengkap merangkumi objektif pengajaran, masa yang diperuntukkan, langkah pembelajaran, aktiviti pelajar, kegiatan guru, dan sebagainya. 


\subsection{MODUL PBL DALAM PENDIDIKAN ISLAM}

\section{Definisi}

PBL adalah singkatan perkataan hasil gabungan 'Islamic' dan 'PBL.' PBL pula merupakan singkatan kepada 'problem based learning' atau pembelajaran berasaskan masalah. Perkataan 'Islamic' pada bahagian awal merupakan terma yang digunakan yang merujuk kepada kursus Pendidikan Islam. Manakala PBL adalah salah satu kaedah pembelajaran berpusatkan pelajar di mana pembelajaran pelajar bermula dari mengenalpasti masalah diikuti dengan proses penyelesaian masalah untuk mencari jawapan (Sarimah \& Abreza, 2011). Pengajaran berasaskan masalah melibatkan empat langkah asas, iaitu pelajar menerima masalah, mengumpulkan data, menyusun data, dan menjelaskan masalah, menganalisis strategi yang digunakan untuk menyelesaikan masalah (Akhiar \& Shamsina, 2014).

Dalam kajian ini, pengkaji memberi nama modul ini sebagai PBL kerana lebih mudah dan senang untuk diingati. Hal ini demikian, tidak bererti bahawa PBL yang biasa digunakan tidak mengikut ajaran Islam tetapi pengkaji memberi nama PBL bersesuian dengan kursus dalam Pendidikan Islam. Dalam kajian ini, strategi pembelajaran berasaskan masalah atau PBL difikirkan sesuai untuk dimasukkan ke dalam modul kerana para pelajar didedahkan dengan pelbagai situasi dalam bentuk konflik atau dilema. Menurut Abd Rahim (1993), penggunaan kaedah situasi konflik bertujuan untuk membantu pelajar menyedari dan mengetahui nilai peribadi dan nilai dalam diri orang lain. Kesedaran dalam kalangan pelajar dapat diterap melalui kaedah situasi konflik dilema melalui aktiviti seperti main peranan, kisah sebenar, penggunaan filem, lakonan, perbincangan kumpulan kecil, permainan atau simulasi. Selain itu juga, pembelajaran menerusi PBL turut menggalakkan pelajar untuk berkongsi nilai peribadi dengan nilai orang lain dan mengenalpasti sistem nilai tertentu atau memeriksa pola tingkah laku peribadi. Amalan kepelbagaian dalam pengajaran Pendidikan Islam juga turut diberi galakan yang tinggi oleh Mohd Aliff et al. (2012) terutamanya dalam pembelajaran yang melibatkan pelajar di institusi pengajian tinggi. Tambahan pula, modul PBL ini adalah menerusi atas talian yang boleh dilayari di link URL http://PBLpoli.wordpress.com

PBL

PBL pada awalnya dibangunkan khas untuk pelajar dalam bidang perubatan. Penggunaan PBL pertama kalinya digunakan pada tahun 1980 oleh Howard Barrows dan beberapa rakannya di Sekolah Perubatan, Universiti McMaster di Hamilton, Ontario, Canada (Barrows \& Tamblyn, 1980; Neville, 2009) dan kemudian tersebar ke seluruh dunia termasuklah Amerika Syarikat, United Kingdom, Denmark, Finland, Perancis, Afrika, dan Sweeden (Savin-Baden \& Major, 2004). Namun disebabkan penggunaan PBL menyumbang banyak manfaat terhadap pembelajaran seperti dapat merangsang pembelajaran pelajar, menjana idea dan memotivasikan pelajar untuk berfikir, PBL telah diperluaskan ke dalam pelbagai bidang termasuklah dalam bidang pendidikan (Barrows \& Tamblyn, 1980). Savin-Baden dan Major (2004) menyatakan bahawa pembelajaran menerusi PBL ini berkembang ke pelbagai bidang kerana keperluan untuk melahirkan golongan profesional yang cekap dan berkualiti tinggi.

Umumnya, PBL adalah salah satu kaedah pembelajaran berpusatkan pelajar. Kaedah pembelajaran ini menyediakan pelajar kepada masalah terlebih dahulu sebagai perangsang sesuatu pembelajaran. Jika dilihat kepada takrifan dari Barrows dan Tamblyn (1980), PBL adalah satu pembelajaran yang terjadi akibat daripada proses memahami atau menyelesaikan sesuatu masalah. Menurut mereka, penemuan masalah adalah langkah pertama dalam proses pembelajaran. Masalah ini seterusnya menjadi penggalak kepada penggunaan pelbagai kemahiran masalah dan penaakulan serta mendorong pelajar mencari maklumat yang baru. Apabila proses ini berlaku, maka organisasi pengetahuan sedia ada dalam diri pelajar dapat terjalin agar mencari solusi untuk menyelesaikan sesuatu masalah.

Wan Syafii (2014) menyatakan bahawa PBL merupakan salah satu strategi pembelajaran yang dikenali sebagai contextual teaching learning yang melibatkan aspek teoritikal dari psikologi tingkahlaku dan teori pembelajaran sosial, namun terdapat pandangan dari pengkaji lain yang menyatakan bahawa PBL juga berlandaskan kepada psikologi kognitif. Jonassen (1999) pula menyatakan bahawa PBL adalah contoh pembelajaran yang baik kerana mempunyai unsur persekitaran pembelajaran secara konstruktivis. Menurut beliau, persekitaran pembelajaran yang dihasilkan menerusi PBL dapat menjurus kepada tiga aspek seperti berikut:

(i) Kefahaman yang dibina adalah berasaskan kepada interaksi dengan persekitaran

(ii) Konflik kognitif adalah rangsangan bagi pembelajaran dan ianya dapat menentukan organisasi pemikiran pelajar terhadap apa yang mereka pelajari.

(iii) Pengetahuan yang dibina adalah hasil dari pertimbangan sosial bergantung kepada tahap kefahaman pelajar itu sendiri.

PBL bermula dengan mengenalpasti masalah diikuti dengan proses penyelesaian masalah untuk mencari jawapan. Menurut Akhiar dam Shamsina (2014), terdapat empat langkah asas untuk mengimplimenkan pembelajaran secara PBL iaitu; 1) pelajar menerima masalah; 2) mengumpulkan data; 3) menyusun data, dan; 4) menjelaskan masalah dan menganalisis strategi yang digunakan untuk menyelesaikan masalah. Selain itu juga, masalah yang diberikan dalam PBL tidak sama dengan masalah seperti biasa kerana PBL bertindak untuk mewujudkan suasana pelajar berfikir dan memberikan idea. Oleh itu, pembentukan masalah perlu bersesuaian dengan pengalaman dalam kehidupan pelajar sehingga masalah yang ditimbulkan menjadi masalah yang kontekstual (Wan Syafii, 2014). Oleh yang demikian, dapat difahami bahawa strategi pembelajaran PBL perlu memberi perhatian terhadap pembentukan senario masalah. Jika masalah yang diwujudkan itu menepati garis panduan seperti yang digariskan maka pengajaran dan pembelajaran menerusi PBL ini akan berjaya diwujudkan.

\subsection{OBJEKTIF KAJIAN}

Terdapat dua objektif kajian yang telah digariskan, iaitu;

(i) Mengenalpasti tahap kefahaman pelajar terhadap Modul PBL dalam Pendidikan Islam

(ii) Mengetahui maklum balas pelajar terhadap pengajaran dan pembelajaran menerusi Modul PBL. 


\subsection{METODOLOGI KAJIAN}

Pengumpulan data yang menggunakan pendekatan gabungan dari kuantitatif dan kualitatif bertujuan untuk mendapatkan maklumat tambahan yang terperinci bagi menyediakan kefahaman mendalam sesuatu permasalahan kajian (Creswell, 2005; Creswell \& Clark, 2007). Menerusi pendekatan gabungan ini, kedua-dua set data kuantitatif dan kualitatif dihubungkan agar dapat membina satu set data yang lain. Set-set ini kemudian akan dikelaskan mengikut tema yang diperolehi secara mendalam selaras dengan matlamat persoalan kajian.

Seramai 41 orang responden di dalam sebuah kelas dipilih secara persampelan bertujuan terlibat dalam kajian. Responden ini merupakan pelajar dari jurusan Teknologi Maklumat dan Komunikasi dan melalui pengajaran dan pembelajaran dengan menggunakan Modul PBL sepanjang satu semester (11 minggu). Pada setiap tajuk pembelajaran, mereka diminta untuk menilai tahap kefahaman terhadap tajuk yang dipelajari. Responden diminta untuk menandakan salah satu nombor untuk menunjukkan persetujuan mereka terhadap pernyataan-pernyataan yang berkaitan dengan kefahaman dalam pembelajaran.

Setelah itu, data yang dikumpulkan daripada borang soal selidik dianalisis dengan menggunakan perisian Statistical Package For The Social Science (SPSS) versi 21. Hanya statistik deskriptif atau perihalan digunakan untuk mendapatkan peratusan dan skor min berdasarkan data yang diperoleh. Bagi tujuan interpretasi penilaian portal ini, penyelidik akan menggunakan Skala Likert Lima Mata yang diberi nilai 1 hingga 5 di mana 1 = Sangat Tidak Setuju, 2 = Tidak Setuju, $3=$ Tidak Pasti, $4=$ Setuju dan $5=$ Sangat Setuju. Pengkaji menggunakan interpretasi skor min dimensi tingkahlaku afektif oleh Nunally (1978) yang dijadikan panduan untuk menganalisis darjah persetujuan responden seperti yang ditunjukkan dalam Jadual 1 di bawah.

Jadual 1 Interpretasi min

\begin{tabular}{cc}
\hline Skor Min & Interpretasi \\
\hline $4.01-5.00$ & Tinggi \\
$3.01-4.00$ & Sederhana Tinggi \\
$2.01-3.00$ & Sederhana Rendah \\
$1.01-2.00$ & Rendah \\
\hline
\end{tabular}

Selain itu, pengkaji juga menjalani sesi temu bual separa berstruktur secara kumpulan mini-fokus (mini-focus groups) bagi mendapatkan pandangan pelajar tentang modul yang telah digunakan. Sebanyak empat orang peserta kajian mengambil bahagian yang merupakan pelajar yang melalui proses pengajaran dan pembelajaran menerusi Modul PBL. Temu bual secara berfokus bertujuan untuk menghasilkan data yang dinamik daripada kumpulan yang sama tahap kebolehan (Barbour, 1999). Kumpulan fokus juga menyediakan peluang untuk pengkaji menganalisis tindakbalas antara peserta kajian (Litosseliti, 2003) dan juga menilai keperluan mereka (Krueger, 1994). Temu bual dibuat berpandukan kepada Protokol Temu bual. Data temu bual ditranskrip dan dianalisis secara tematik menggunakan perisian Nvivo 10.

\subsection{DAPATAN KAJIAN}

Jadual 2 di bawah menunjukkan tahap kefahaman pelajar terhadap 11 topik yang diajarkan sepanjang satu semester di Politeknik. Setiap item yang dinyatakan adalah berdasarkan kepada objektif pembelajaran bagi sesebuah topik yang terkandung di dalam Modul PBL.

Jadual 2 Tahap kefahaman pembelajaran

\begin{tabular}{|c|c|c|c|c|c|}
\hline \multirow[t]{2}{*}{ Tajuk } & \multirow[t]{2}{*}{ Pernyataan } & \multicolumn{3}{|c|}{$\begin{array}{l}\text { Peratus }(\%) \\
\text { Frekuensi }(f)\end{array}$} & \multirow[t]{2}{*}{$\begin{array}{l}\text { Purata } \\
\text { Min }\end{array}$} \\
\hline & & TP & $\mathbf{S}$ & SS & \\
\hline \multirow[t]{3}{*}{ Asas Akidah } & Saya mengetahui pelbagai cara untuk memantapkan akidah & $\begin{array}{c}17.1 \\
(7)\end{array}$ & $\begin{array}{l}56.1 \\
(23)\end{array}$ & $\begin{array}{l}26.8 \\
(11)\end{array}$ & \multirow{3}{*}{4.07} \\
\hline & Saya dapat memberi cadangan kaedah untuk memantapkan akidah & $\begin{array}{l}24.4 \\
(10)\end{array}$ & $\begin{array}{l}48.8 \\
(20)\end{array}$ & $\begin{array}{l}26.8 \\
(11)\end{array}$ & \\
\hline & Saya dapat mengamalkan pelbagai cara untuk meningkatkan akidah & $\begin{array}{l}17.1 \\
(7)\end{array}$ & $\begin{array}{l}56.1 \\
(23)\end{array}$ & $\begin{array}{l}26.8 \\
(11)\end{array}$ & \\
\hline \multirow{3}{*}{$\begin{array}{l}\text { Al-Quran \& Al- } \\
\text { Hadith }\end{array}$} & Saya dapat memahami pelbagai cara untuk membela Al-Quran \& Hadith & $\begin{array}{l}9.8 \\
(4)\end{array}$ & $\begin{array}{l}56.1 \\
(23)\end{array}$ & $\begin{array}{l}34.1 \\
(14)\end{array}$ & \multirow{3}{*}{4.11} \\
\hline & Saya dapat mencadangkan langkah-langkah untuk membela Al-Quran \& Hadith & $\begin{array}{l}22 \\
(9)\end{array}$ & $\begin{array}{l}56.1 \\
(23)\end{array}$ & $\begin{array}{l}22 \\
(9)\end{array}$ & \\
\hline & $\begin{array}{l}\text { Saya dapat memberikan contoh akhlak yang baik demi mempertahankan Al-Quran \& } \\
\text { Hadith }\end{array}$ & $\begin{array}{c}19.5 \\
(8)\end{array}$ & $\begin{array}{l}51.2 \\
(21) \\
\end{array}$ & $\begin{array}{l}29.3 \\
(12)\end{array}$ & \\
\hline \multirow{3}{*}{ Agama Islam } & Saya dapat mengetahui pelbagai cara untuk memelihara agama & $\begin{array}{l}4.9 \\
(2)\end{array}$ & $\begin{array}{l}53.7 \\
(22)\end{array}$ & $\begin{array}{l}41.5 \\
(17)\end{array}$ & \multirow{3}{*}{4.26} \\
\hline & Saya dapat mencadangkan langkah-langkah untuk memelihara agama & $\begin{array}{c}14.6 \\
(6)\end{array}$ & $\begin{array}{l}56.1 \\
(23)\end{array}$ & $\begin{array}{l}29.3 \\
(12)\end{array}$ & \\
\hline & Saya bersedia menempuhi pelbagai ujian dan cabaran dalam agama & $\begin{array}{l}7.3 \\
(3) \\
\end{array}$ & $\begin{array}{l}58.5 \\
(24) \\
\end{array}$ & $\begin{array}{l}34.1 \\
(14) \\
\end{array}$ & \\
\hline \multirow{3}{*}{ Sistem Sosial } & Saya dapat mengetahui pelbagai cara untuk menyelesaikan masalah sosial & $\begin{array}{c}12.2 \\
(5)\end{array}$ & $\begin{array}{l}68.3 \\
(28)\end{array}$ & $\begin{array}{c}19.5 \\
(8)\end{array}$ & \multirow{3}{*}{3.99} \\
\hline & Saya dapat mencadangkan cara-cara untuk menangani masalah sosial & $\begin{array}{c}19.5 \\
(8)\end{array}$ & $\begin{array}{c}61 \\
(25)\end{array}$ & $\begin{array}{c}19.5 \\
(8)\end{array}$ & \\
\hline & Saya bersedia untuk bertanggungjawab untuk menyelesaikan masalah sosial & 29.3 & 51.2 & 19.5 & \\
\hline
\end{tabular}




\begin{tabular}{|c|c|c|c|c|c|}
\hline & & $(12)$ & $(21)$ & $(8)$ & \\
\hline \multirow{6}{*}{ Jenayah } & Saya dapat memahami pelbagai cara untuk membanteras jenayah & 14.6 & 68.3 & 17.1 & \multirow{6}{*}{3.84} \\
\hline & & $(6)$ & (28) & (7) & \\
\hline & Saya dapat memberi cadangan untuk mengurangkan jenayah & 34.1 & 61 & 4.9 & \\
\hline & \multirow{3}{*}{ Saya bersedia untuk bertindak membanteras jenayah } & (14) & $(25)$ & (2) & \\
\hline & & 31.7 & 58.5 & 9.8 & \\
\hline & & $(13)$ & (24) & (4) & \\
\hline \multirow{6}{*}{ Muamalah } & \multirow[t]{2}{*}{ Saya dapat memahami cara bermuamalah dalam Islam } & 19.5 & 63.4 & 17.1 & \multirow{6}{*}{3.89} \\
\hline & & $(8)$ & (26) & $(7)$ & \\
\hline & \multirow[t]{2}{*}{ Saya dapat memberi cadangan bagaimana kaedah bermuamalah dalam Islam } & 26.8 & 58.5 & 14.6 & \\
\hline & & $(11)$ & (24) & $(6)$ & \\
\hline & \multirow[t]{2}{*}{ Saya dapat mengamalkan cara untuk bermuamalah dalam Islam } & 26.8 & 63.4 & 9.8 & \\
\hline & & $(11)$ & $(26)$ & $(4)$ & \\
\hline \multirow{6}{*}{$\begin{array}{l}\text { Pentadbiran \& } \\
\text { Pengurusan }\end{array}$} & \multirow[t]{2}{*}{ Saya dapat memahami kaedah pentadbiran $\&$ pengurusan dalam Islam } & 17.1 & 63.4 & 19.5 & \multirow{6}{*}{4.00} \\
\hline & & (7) & (26) & $(8)$ & \\
\hline & Saya dapat memberi cadangan bagaimana untuk mengamalkan pentadbiran \& & 26.8 & 53.7 & 19.5 & \\
\hline & pengurusan yang bertepatan dalam Islam & $(11)$ & (22) & $(8)$ & \\
\hline & Saya bersedia untuk mengamalkan akhlak yang mulia dalam pentadbiran \& & 19.5 & 56.1 & 24.4 & \\
\hline & pengurusan & $(8)$ & (23) & (10) & \\
\hline \multirow{6}{*}{ Kepimpinan } & Saya dapat memahami cara kepimpinan berpandukan Islam & 9.8 & 63.4 & 26.8 & \multirow{6}{*}{4.08} \\
\hline & \multirow{3}{*}{ Saya dapat memberi cadangan bagaimana amalan kepimpinan dalam Islam } & (4) & (26) & (11) & \\
\hline & & 14.6 & 68.3 & 17.1 & \\
\hline & & (6) & (28) & $(7)$ & \\
\hline & \multirow{2}{*}{$\begin{array}{l}\text { Saya dapat bersedia untuk mengamalkan amalan kepimpinan yang bertepatan dalam } \\
\text { Islam }\end{array}$} & 17.1 & 61 & 22 & \\
\hline & & (7) & (25) & (9) & \\
\hline \multirow{6}{*}{$\begin{array}{l}\text { Merealisasikan } \\
\text { Brunei }\end{array}$} & \multirow[t]{2}{*}{ Saya dapat mengetahui cara merealisasikan negara Brunei sebagai negara Zikir } & 9.8 & 48.8 & 41.5 & \multirow{6}{*}{4.24} \\
\hline & & (4) & (20) & (17) & \\
\hline & \multirow{4}{*}{$\begin{array}{l}\text { Saya dapat memberi cadangan bagaimana cara untuk merealisasikan negara Brunei } \\
\text { sebagai negara Zikir } \\
\text { Saya dapat mengamalkan akhlak belia Islam bertepatan dengan negara Zikir }\end{array}$} & 22 & 43.9 & 34.1 & \\
\hline & & (9) & (18) & (14) & \\
\hline & & 9.8 & 53.7 & 36.6 & \\
\hline & & (4) & (22) & (15) & \\
\hline \multirow{6}{*}{ Pekerjaan } & \multirow[t]{2}{*}{ Saya dapat mengetahui perlakuan akhlak mulia yang patut diamalkan dalam pekerjaan } & 2.4 & 48.8 & 48.8 & \multirow{6}{*}{4.32} \\
\hline & & (1) & (20) & (20) & \\
\hline & \multirow{4}{*}{$\begin{array}{l}\text { Saya dapat memberi cadangan bagaimana untuk mengamalkan akhlak mulia dalam } \\
\text { pekerjaan } \\
\text { Saya bersedia untuk mengamalkan akhlak yang mulia apabila bekerja nanti }\end{array}$} & 12.2 & 56.1 & 31.7 & \\
\hline & & (5) & (23) & (13) & \\
\hline & & 9.8 & 51.2 & 39 & \\
\hline & & (4) & (21) & (16) & \\
\hline \multirow{6}{*}{ Seni Bina } & \multirow[t]{2}{*}{ Saya dapat mengetahui cara untuk memelihara seni bina Islam } & 9.8 & 65.9 & 24.4 & \\
\hline & & (4) & $(27)$ & $(10)$ & \\
\hline & Saya dapat memberi idea untuk memelihara seni bina Islam & 22 & 53.7 & 24.4 & 4.09 \\
\hline & & $(9)$ & $(22)$ & $(10)$ & \\
\hline & Saya dapat menonjolkan akhlak yang mulia untuk menjaga seni bina Islam & 19.5 & 51.2 & 29.3 & \\
\hline & & $(8)$ & $(21)$ & $(12)$ & \\
\hline
\end{tabular}

Berdasarkan kepada jadual di atas, skor min bagi setiap tajuk pembelajaran adalah pada tahap yang baik. Sebanyak tujuh tajuk pembelajaran yang memperoleh skor min pada tahap yang tinggi berbanding hanya empat sahaja tajuk pembelajaran yang memperoleh skor min pada tahap sederhana tinggi. Walau bagaimanapun, dapatan persetujuan responden adalah konsisten berdasarkan kepada pemilihan jawapan yang diberikan. Jika dilihat dengan lebih teliti, skor min bagi tajuk-tajuk yang berada pada tahap yang tinggi adalah antara 4.07 hingga 4.32. Manakala skor min bagi tajuk-tajuk pada tahap yang sederhana tinggi pula adalah antara 3.89 hingga 4.00.

Walaupun empat tajuk pembelajaran ini berada pada tahap yang sederhana tinggi, namun skor-skor min dapatan yang diperolehi adalah menghampiri kepada tahap yang tinggi. Hal ini demikian menunjukkan bahawa responden masih lagi dapat mengikuti pembelajaran dengan baik. Antara tajuk pembelajaran yang memperoleh skor min pada tahap yang tinggi ialah tajuk Asas Akidah, Al-Quran dan AlHadith, Agama Islam, Kepimpinan, Merealisasikan Brunei, Pekerjaan, dan Seni Bina. Manakala bagi tajuk pembelajaran yang memperoleh skor min pada tahap sederhana tinggi pula ialah Sistem Sosial, Jenayah, Muamalah serta Pentadbiran dan Pengurusan.

\section{Dapatan Temu Bual}

Dari dapatan temu bual yang dijalankan, pengkaji telah mengenalpasti beberapa tema utama maklum balas peserta kajian terhadap pengajaran dan pembelajaran yang menggunakan Modul PBL. Antara tema-tema utama yang dapat dikenalpasti ialah peningkatan tumpuan, perkongsian maklumat, pemikiran kritikal, menarik, berbeza, berdikari, dan nilai bekerjasama.

\section{Peningkatan Tumpuan}

Majoriti peserta kajian kumpulan eksperimen bersetuju untuk menyatakan bahawa penggunaan Modul PBL dapat meningkatkan "tumpuan" dan mengelakkan diri dari rasa "mengantuk" di dalam bilik darjah. Peserta kajian PKE3 menyatakan bahawa Modul PBL yang dilaluinya "memaksa perhatian pelajar" untuk fokus dalam "menyelesaikan masalah" dalam sesebuah tajuk. Peserta kajian PKE4 turut bersetuju dengan pernyataan ini, beliau turut mengakui bahawa "tumpuan" pelajar dapat ditingkatkan. Sebaliknya, penggunaan kaedah biasa boleh menyebabkan beliau "lupa" apa yang dipelajarinya. Keadaan ini dapat dijelaskan melalui apa yang dilalui oleh perserta kajian PKE3 semasa berada di dalam bilik darjah. Kata beliau; 
“...senario-senario itu, ia dapat tolong saya menumpukan pada kerja, dan ampitkan saya kerja dalam based saya sendiri. Sekiranya lecturer dulu yang membaca sendiri atau cikgu mengajar di depan saja, boleh hilang tumpuan...”

\section{Pemikiran Kritikal}

Peningkatan tumpuan dan perhatian pelajar di dalam kelas ini berlaku disebabkan oleh teknik yang diterapkan dalam Modul PBL berkenaan. Menurut peserta kajian PKE1 dan PKE4, kaedah "kritikal thinking" yang diterapkan dalam pembelajaran menjadikan mereka cuba untuk berfikir "out of the box". Sebagaimana yang dikatakan oleh PKE1;

"...PBL ani membuatkan student mahu untuk explore the idea. Maksudnya idea tu boleh, since ia in group so PBL ani basically ia mengajar student untuk berfikir like, out of the box and, basically like sharing ideas dengan yang lainlah. So, pendapat tu bukan satu sajalah. Kitani boleh menilai and mendapat jawapan jua dari student-student yang lain..."

\section{Perkongsian Maklumat}

Kesemua peserta kajian bersetuju untuk menyatakan bahawa pembelajaran menggunakan Modul PBL dapat "berkongsi" maklumat dengan rakan-rakan yang lain. Perkongsian maklumat ini kerap berlaku terutamanya semasa "proses menyelesaikan masalah" yang diberikan dalam modul berkenaan. Mereka dapat maklumat dari "pandangan” yang diutarakan oleh rakan-rakan mereka yang lain.

\section{Menarik}

Majoriti daripada peserta kajian (PKE1, PKE2 \& PKE4) menyatakan bahawa mereka "puas hati" dengan penggunaan Modul PBL dalam kursus Pendidikan Islam. Bahkan peserta kajian PKE2 menjelaskan bahawa pembelajaran menerusi Modul PBL adalah "sangat unik" dan "menarik hati" para pelajar. Kata beliau;

“...Memang cukup berpuas hati, siapa yang tidak berpuas hati rugilah. Kerana pembelajaran itu, sangat unik bagi kami, dan menarik hati pada penuntut-penuntut terutamanya kepada belia-belia yang mempunyai masalah-masalah, masalah Islamikla..."

\section{Berbeza}

Selain itu, peserta kajian PKE2 menyatakan bahawa pengalaman belajar menggunakan Modul PBL adalah "berbeza" dengan pembelajaran sebelum ini. Modul PBL lebih menumpukan kepada "problem solving" dan mereka "dapat membincangkan cara-cara untuk menyelesaikan masalah" di dalam kumpulan. Senario-senario masalah yang diberikan juga merupakan "sesuatu yang tidak pernah kami ketahui, jadi kami sentiasa berwaspada dengan apa yang terjadi." Begitu juga dengan peserta kajian PKE1, penggunaan Modul PBL menjadikan diri beliau lebih "berani" dan meningkatkan "keyakinan diri" terutamanya dalam sesi perbincangan dan membentangkan tugasan di hadapan bilik darjah. Menurut PKE1;

“...saya sendiri pun puas hati, ani kira first timelah belajar dalam pembelajaran seperti PBL ani ah. Its different dari pembelajaran yang dulu. And PBL ani membuat kami yang macam pemalu, ada yang inda berani so arah PBL ni kan ada presentation, that makes yang kami yang pemalu ani, ataupun inda berani untuk bersuara memberanikan diri untuk, explore ourself dengan orang ramai. Membiasakan diri present di hadapan kelas. Which is in every class kami mempresent, so dari minggu ke minggu, boleh dilihat perbezaannyalah dari kami yang malu, sampai kami inda malu (ketawa kecil). So, atu sebenarnya baguslah sebab student yang inda active pun jadi mahu bercakap, mahu bagi pandangan macam tu...,

\section{Berdikari}

Peserta kajian PKE2 turut mengakui bahawa pembelajaran menerusi Modul PBL dapat memupuk "sikap" untuk "menyelesaikan masalah" atas usaha sendiri dan "tidak bergantung" kepada orang lain. Peserta kajian lain turut bersetuju bahawa modul ini dapat menjadikan mereka lebih berdikari berbanding dengan pengajaran biasa. Hal ini dapat dilihat melalui pernyataan yang dijelaskan oleh peserta kajian PKE2;

“...Permulaannya memang tidak. kerana hanya satu pihak sahaja yang membagi data tersebut. Dan pada minggu kedua kami semakin mempunyai satu misi iaitu bekerjasama. Dan pada minggu ketiga pula kami berani untuk membagi satu cadangan bersama-sama. Dan pada minggu ke empat berani pula untuk mengatakan sesuatu yang baru. Dan minggu kelima dan seterusnya, sahabat-sahabat tersebut mempunyai pandangan tersendiri. Bukan sahaja pada satu individu, malahan ketiga-tiga individu itu bekerjasama membagi pendapat yang sangat bernas..."

\section{Nilai Bekerjasama}

Majoriti peserta kajian bersetuju bahawa kursus Pendidikan Islam yang mereka lalui sepanjang satu semester dapat memupuk nilai "bekerjasama" antara ahli di dalam kumpulan. Hal ini diakui sendiri oleh peserta kajian PKE2 semasa menggambarkan nilai bekerjasama di dalam kumpulan tugasan mereka. Walaupun pada awalnya sikap bekerjasama ini sukar dan kurang dipraktikkan dalam kalangan ahli di dalam kumpulan, namun nilai bekerjasama ini semakin menyerlah apabila tugasan semakin bertambah. Menurut beliau

“...Permulaannya memang tidak. kerana hanya satu pihak sahaja yang membagi data tersebut. Dan pada minggu kedua kami semakin mempunyai satu misi iaitu bekerjasama. Dan pada minggu ketiga pula kami berani untuk membagi satu 
cadangan bersama-sama. Dan pada minggu ke empat berani pula untuk mengatakan sesuatu yang baru. Dan minggu kelima dan seterusnya, sahabat-sahabat tersebut mempunyai pandangan tersendiri. Bukan sahaja pada satu individu, malahan ketiga-tiga individu itu bekerjasama membagi pendapat yang sangat bernas..."

\subsection{PERBINCANGAN}

Pengajaran dan pembelajaran menggunakan Modul PBL mendapat maklum balas yang sangat positif dari pihak pengguna, iaitu pelajar kumpulan eksperimen. Modul PBL yang direka bentuk dan dibangunkan menggunakan pembelajaran berasaskan masalah ini terbukti dapat meningkatkan pengetahuan pelajar. Amalan pembelajaran berasaskan masalah yang dilaksanakan dalam kajian ini memberi peluang kepada pelajar untuk aktif melibatkan diri, saling bekerjasama dan berbincang antara ahli dalam kumpulan mereka.

Selain itu, penggunaan modul ini dapat membantu pelajar untuk mewujudkan suasana pembelajaran secara berkumpulan, saling tolong-menolong menyelesaikan masalah, dan bekerjasama. Hal ini adalah seiring dengan apa yang dijelaskan oleh Akcel dan Isaac (2004) dan Kuo-Hung et al. (2008) dalam kajian mereka. Tambahan pula, kajian oleh Yeh (2010) membuktikan bahawa pelajar yang mengikuti pembelajaran secara PBL lebih bermotivasi daripada keadaan biasa. Hal ini demikian jelas menunjukkan bahawa budaya pembelajaran secara PBL berupaya meningkatkan semangat bekerjasama, sifat berpasukan, dan keyakinan diri dalam menyelesaikan masalah.

Kajian turut mengenalpasti bahawa panduan yang diberikan dapat membantu pelajar mencari maklumat untuk menyelesaikan masalah. Dapatan ini seiring dengan kajian oleh Jeong dan Hmelo-Silver (2010) dalam mendapatkan bantuan semasa menyelesaikan masalah. Walaupun kajian mereka mendedahkan pelajar yang berpencapaian rendah memerlukan panduan yang lebih banyak berbanding dengan pelajar berpencapaian tinggi namun, kedua-dua pelajar mampu menggunakan sumber yang disediakan di atas talian. Para pelajar juga bermotivasi untuk mencari jalan penyelesaian bersama-sama. Sebaliknya, mereka akan mengalami kesukaran jika tidak dapat mencari kata sepakat dalam menyelesaikan tugasan yang diberikan.

Di samping itu, pemupukan sifat berdikari turut dikenalpasti oleh Kivela dan Kivela (2005) dan Sungur dan Tekkaya (2006) dalam kajian mereka. Kajian oleh Kivela dan Kivela mendapati bahawa sikap pengaturan kendiri pelajar dapat ditingkatkan melalui pembelajaran secara PBL. Manakala kajian oleh Sungur dan Tekkaya (2006) pula telah mendapati bahawa sikap pembelajaran kendiri pelajar turut dapat ditingkatkan melalui kaedah yang sama. Hal ini demikian menunjukkan bahawa pembelajaran secara PBL bukan sahaja dapat membantu pelajar untuk lebih bersikap berdikari dalam memandu pelajar untuk merancang pembelajaran mereka malahan, kaedah ini juga dapat dan menetapkan matlamat pembelajaran dalam usaha pencarian maklumat. Pada masa yang sama, penggunaan masa dalam pembelajaran perlu dijaga dengan baik bagi memastikan setiap kumpulan dapat menyelesaikan masalah yang diberikan.

Selain itu, aspek amalan pengajaran berkesan turut diberikan keutamaan dalam perlaksanaan Modul PBL ini. Antara faktor yang memberi penyumbang terhadap amalan pengajaran berkesan dalam kajian ini adalah penerapan kemahiran berfikir aras tinggi yang melibatkan kemahiran berfikir secara kritikal, berfikir secara kreatif dan kemahiran menyelesaikan masalah. Kajian-kajian lepas kekal menyatakan bahawa penggunaan PBL dapat mempengaruhi hasil pembelajaran pada masa yang sama menyediakan kemahiran berfikir aras tinggi, pemikiran kreatif, penyelesaian masalah, pemikiran logik dan membuat keputusan (Faridah, 2009; Juba \& Ricca, 2014; Sendag \& Odabasi, 2009; Tarhan \& Acar-Sesen, 2013; Wan Syafii, 2014). Hal ini jelas menunjukkan bahawa kesemua elemen ini merupakan kemahiran yang diperlukan untuk mewujudkan sebuah platform pembelajaran pada abad ke-21.

\subsection{PENUTUP}

Penggunaan Modul PBL merupakan kaedah alternatif yang boleh diketengahkan dan diberi pendedahan kepada para pendidik dalam bidang Pendidikan Islam dalam pengajaran dan pembelajaran yang mereka laksanakan. Dengan mengaplikasikan strategi pembelajaran ini, para pelajar dapat meningkatkan lagi kefahaman terhadap pengajaran dan pembelajaran dalam Pendidikan Islam. Pada masa yang sama penggunaan strategi pembelajaran ini menjadikan mereka terlibat secara aktif, bekerjasama dengan rakan-rakannya yang lain, menambah keyakinan diri, saling mengemukakan idea dan sebagainya seiring dengan tuntutan pembelajaran semasa pada abad ke-21. Para pendidik juga dapat menjadikan modul ini sebagai bahan panduan dalam melaksanakan pembelajaran secara PBL dalam pengajaran dan pembelajaran. Modul ini dapat dijadikan contoh bagaimana menghasilkan bahan dan proses menyediakan pengajaran.

\section{Rujukan}

Abd. Rahim Abd Rashid. (1993). Pendidikan Nilai Merentasi Kurikulum. Kuala Lumpur: Dewan Bahasa \& Pustaka.

Akcell Chii-Chung Chiang \& Isaac Pak-Wah Fung. (2004). Redesigning Chat Forum For Critical Thinking In A Problem-Based Learning Environment. Internet and Higher Education, 7, 311-328

Akhiar Pardi \& Shamsina Samsuddin. (2014). Rancangan Pengajaran Harian dalam Pengajaran dan Pembelajaran. Puchong: Penerbitan Multimedia Sdn. Bhd.

Aliff Nawi \& Gamal Abdul Nasir Zakaria. (2016). Pembangunan \& Penilaian Portal iPBL dalam Kursus Pendidikan Islam di Politeknik Brunei. Jurnal Komunikasi, Malaysian Journal of Communication, 32(1), 261-285 [23 Dis 2016]

Aliff Nawi, Gamal Abdul Nasir Zakaria, Norkhairiah Hashim \& Chua Chy Ren (2015) Penilaian Kualiti Modul iPBL: Aspek Kesahan Dan Kebolehpercayaan. Journal of Quality Measurement and Analysis, 11 (2), 1-10. http://www.ukm.my/jqma/v11_2/jqma-11-2-paper1.pdf [13 Jan 2017]

Barbour, R. S., Kitzinger, J. (1999). Developing Focus Group Research: Politics. Theory and Practice. London: Sage Publications.

Barrows, H.S. \& Tamblyn, R.M. (1980). Problem-Based Learning - An Approach to Medical Education. New York: Springer

Creswell, J. W. (2005). Educational Research: Planning, Conducting, And Evaluating Quantitative And Qualitative Research (2nd ed.). Upper Saddle River, NJ: Pearson.

Faridah Hanim Yahya. (2009). Perisian Kursus Multimedia Interaktif Untuk Mata Pelajaran Matematik (Topik Set) menggunakan Pendekatan Pembelajaran Berasaskan Masalah (PBL Math-Set). Tesis Doktor Falsafah, Fakulti Teknologi \& Sains Maklumat. Universiti Kebangsaan Malaysia.

Jeong, H. \& Hmelo-Silver, C. E. (2010). Productive Use Of Learning Resources In An Online Problem-Based Learning Environment. Computers in Human Behavior, 26(10), 84-99

Jonassen, D. H. (1999). Constructivist Learning Environments. Dlm, Reigeluth C. (pnyt.), Instructional Design Theories And Models, 215-239. Mahwah, NJ: Lawrence Erlbaum. 
Juba, K. M. \& Ricca, B. P. (2014). Design of A Problem-Based Learning Pain And Palliative Care Elective Course. Currents in Pharmacy Teaching and Learning, 6 , $421-428$

Kivela, J., \& Kivela, R. J. (2005). Student Perceptions Of An Embedded Problem-Based Learning Instructional Approach In A Hospitality Undergraduate Programme. International Journal of Hospitality Management, 24, 437-464.

Krueger, R. A. (1994). Focus Group: A Practical Guide for Applied Research. London: Sage Publications.

Kuo-Hung Tseng, Feng Kuang Chiang, Wen-Hua Hsu. (2008). Interactive Processes And Learning Attitudes In A Web-Based Problem-Based Learning (PBL) Platform. Computers in Human Behavior, 24, 940-955

Litosseliti, L. (2003). Using Focus Groups in Research. London: Continuum

Mohd Aliff Mohd Nawi, Ezad Azraai Jamsari, Mohd Isa Hamzah, Adibah Sulaiman \& Azizi Umar. 2012. The Impact of Globalization on Current Islamic Education. Australian Journal of Basic and Applied Sciences, 6(8), 74-78 http://www.ajbasweb.com/ajbas/2012/August/74-78.pdf

Neville, A. J. (2009). Problem-Based Learning and Medical Education Forty Years on. Medical Principles and Practice, 18(1), 1-9.

Nunally, J. C. (1978). Psycometric Theory. New York: Mc Graw Hill Book Company.

Rosnah Ahmad Zain. (2002). Pembinaan Modul Bercetak Untuk Pengajaran Dan Pembelajaran Bersepadu Adobe Photoshop dan Reka Bentuk Grafik Asas. Projek Sarjana. Bangi, UKM

Sarimah Ismail \& Abreza Atan. (2011). Aplikasi Pendekatan Penyelesaian Masalah dalam Pengajaran Mata Pelajaran Teknikal dan Vokasional di Fakulti Pendidikan UTM. Journal of Educational Psycology and Counseling, 3(11), 113-144. http://eprints.utm.my/13385/1/JEPC-2011-2-005.pdf [27 Jan 2015]

Savin-Baden, M., \& Major, H. C. (2004). Foundations of Problem-Based Learning. Birkshire, England: The Society for Research into Higher Education \& Open University Press.

Sendag, S. \& Odabasi, H. F. (2009). Effects of an Online Problem Based Learning Course On Content Knowledge Acquisition And Critical Thinking Skills. Computers \& Education, 53, 132-141.

Sidek Mohd Noah \& Jamaludin Ahmad. (2005). Pembinaan Modul: Bagaimana Membina Modul Latihan dan Modul Akademik. Serdang: Penerbit Universiti Putra Malaysia.

Sungur, S., \& Tekkaya, C. (2006). Effects of Problem-Based Learning And Traditional Instruction On Selfregulated Learning. The Journal of Educational Research, $99,307-317$

Tarhan, L. \& Acar-Sesen, B. (2013). Problem Based Learning In Acids And Bases: Learning Achievements And Students' Beliefs. Journal of Baltic Science Education, 12(5), 565-578.

Wan Syafii. (2014). Keberkesanan Penggunaan Modul Pembelajaran Berasaskan Masalah dalam Pengajaran dan Pembelajaran Biologi di Sekolah Menengah. Tesis Doktor Falsafah Fakulti Pendidikan, Universiti Kebangsaan Malaysia.

Winkel, W. S. (2004). Psikologi Pengajaran. Ed. Ke-6. Yokyakarta: Media Abadi.

Yeh, Yu-chu. (2010). Integrating Collaborative PBL with Blended Learning to Explore Preservice Teachers' Development of Online Learning Communities. Teaching and Teacher Education: An International Journal of Research and Studies, 26(8), 1630-1640.

Yusup Hashim. (1997). Media Pengajaran Untuk Pendidikan Dan Latihan. Selangor: Fajar Bakti Sdn Bhd. 